\author{
ANDRZEJ SZMYT \\ ORCID: 0000-0003-3101-4838 \\ Uniwersytet Gdański
}

\title{
EUROPEJSKI BANK CENTRALNY
}

\begin{abstract}
Abstrakt: Artykuł jest poświęcony statusowi Europejskiego Banku Centralnego w Europejskim Systemie Banków Centralnych. Autor omówił skład i kompetencje organu, jego funkcje i zadania, wewnętrzne organy decyzyjne i tryb postępowania. Ukazano też powiązanie z systemem krajowych banków centralnych, w tym aktualny status Narodowego Banku Polskiego i zmiany konstytucyjne, konieczne w przyszłości dla wprowadzenia w Polsce waluty euro.
\end{abstract}

Słowa kluczowe: Europejski Bank Centralny, Europejski System Banków Centralnych, eurosystem, Narodowy Bank Polski

1. Wśród przewidzianych traktatowo siedmiu „instytucji” Unii Europejskiej wskazany został także „Europejski Bank Centralny” (EBC) ${ }^{1}$. Tamże wskazano (art. 13 ust. 3), że postanowienia dotyczące EBC znajdują się w Traktacie o funkcjonowaniu Unii Europejskiej (wersja skonsolidowana). Chodzi tu o art. 282-284 TFUE oraz objęte odesłaniem art. 127-133 i art. 138. Powstanie EBC przewidział Traktat z Maastricht z 1992 roku, ale poprzednikiem EBC był Europejski Instytut Walutowy, który powstał w 1994 roku i w 1998 roku został przekształcony w Europejski Bank Centralny. Siedziba EBC znajduje się we Frankfurcie nad Menem.

EBC korzysta na terenie państw członkowskich UE z wszelkich przywilejów i immunitetów, jakie są niezbędne do wykonywania jego zadań, na warunkach ustalonych w Protokole w sprawie przywilejów i immunitetów Unii Europejskiej.

Zgodnie z przytoczonym art. 282 TFUE EBC i krajowe banki centralne tworzą Europejski System Banków Centralnych (ESBC). EBC i krajowe banki centralne państw członkowskich UE, których walutą jest euro - tworzące Eurosystem - prowadzą politykę pieniężną Unii. Głównym celem ESBC jest utrzymanie stabilności cen. Bez uszczerbku dla tego celu wspiera on ogólne polityki gospodarcze w Unii, mając na względzie przyczynianie się do osiągnięcia celów Unii. ESBC działa w poszanowaniu zasady otwartej gospodarki rynkowej z wolną

1 Traktat o Unii Europejskiej, w wersji skonsolidowanej opubl. w Dz. Urz. UE 2016 C 202, s. 1 , art. 13 ust. 1 . 
konkurencją, sprzyjając efektywnej alokacji zasobów. Działania zakładają poszanowanie określonych zasad przewodnich — stabilnych cen, zdrowych finansów publicznych i warunków pieniężnych oraz trwałej równowagi płatniczej (art. 282 ust. $1-2$ w zw. z art. 127 ust. 1 i art. 119 ust. 1 i 3 TFUE). Podstawowe zadania ESBC (art. 127 ust. 2) polegają na:

— definiowaniu i urzeczywistnianiu polityki pieniężnej Unii,

- przeprowadzaniu operacji walutowych,

— utrzymaniu i zarządzaniu oficjalnymi rezerwami walutowymi państw członkowskich,

— popieraniu należytego funkcjonowania systemów płatniczych.

Do realizacji powyższych celów i zadań $\mathrm{EBC}$ między innymi pełni funkcje doradcze. Jest on konsultowany (art. 127 ust. 4):

- w sprawie każdego projektowanego aktu Unii w dziedzinach podlegających jego kompetencji,

— przez władze krajowe w sprawie każdego projektu regulacji w dziedzinach podlegających jego kompetencji.

EBC może - w dziedzinach podlegających jego kompetencji — przedkładać opinie właściwym instytucjom, organom lub jednostkom organizacyjnym Unii bądź władzom krajowym.

Zgodnie $\mathrm{z}$ art. $132 \mathrm{TFUE}$ - w celu wykonania zadań powierzonych ESBC, na warunkach traktatowych i statutowych - EBC uchwala rozporządzenia i podejmuje decyzje oraz wydaje zalecenia i opinie. Może zadecydować o opublikowaniu swych decyzji, zaleceń i opinii. W przypadku nieposzanowania jego rozporządzeń i decyzji jest upoważniony do nakładania na przedsiębiorstwa grzywien i okresowych kar pieniężnych. EBC ma wyłączne prawo do upoważniania do emisji banknotów euro w Unii (art. 128 ust. 1).

EBC może też otrzymać — w trybie art. 127 TFUE — szczególne zadania dotyczące polityk w dziedzinie „nadzoru ostrożnościowego” nad instytucjami kredytowymi i innymi instytucjami ubezpieczeniowymi (art. 127 ust. 6). Z początkiem 2013 roku proces wdrażania mechanizmu „nadzorczego” EBC objął banki, które otrzymały pomoc ze środków publicznych lub wystąpiły o jej przyznanie, ale od 2014 roku mechanizm ten rozszerzono, obejmując nim wszystkie banki. Na podstawie art. 127 ust. 6 TFUE Rada wydała rozporządzenie Rady (UE) nr 1024/2013 z 15 października 2013 roku, powierzające EBC szczególne zadania w odniesieniu do polityki związanej z nadzorem ostrożnościowym nad instytucjami kredytowy$\mathrm{mi}^{2}$. Rozporządzenie powierzyło EBC szczególne zadania w zakresie nadzoru mikroostrożnościowego, to jest nadzoru, który ma średniookresowo zminimalizować — ale nie wykluczać - możliwość upadłości istotnych instytucji kredytowych. Oznacza to dla EBC takie między innymi zadania, jak licencjonowanie banków (wydawanie i cofanie zezwolenia na utworzenie oraz podjęcie działalności), oce-

2 Dz. Urz. 29.10.2013 L 287/63. 
na skutków nabywania znacznych pakietów akcji, ocena zgodności dokumentacji, ocena zgodności z wymogami co do posiadania funduszy własnych, ocena płynności, podawanie do publicznej wiadomości informacji w wymienionych materiach, ocena zgodności zasad zarządzania z wymogami w tym zakresie, przeprowadzenie przeglądów (na przykład tak zwanych stress testów). Za wykonanie wspomnianego rozporządzenia EBC odpowiada przed Parlamentem Europejskim i Radą.

W praktyce EBC występuje też jako pożyczkodawca ostatniej instancji (lender of last resort), udzielając awaryjnej pomocy finansowej instytucji (instytucjom), która w wyniku kryzysu finansowego stała się niewypłacalna, w następstwie czego doszło do zaburzeń w systemie finansowym, wywołujących efekt „zarażania” (contagion effect) jednej instytucji finansowej przez inną. EBC nie dysponuje wprost traktatowymi (statutowymi) podstawami do pełnienia tej funkcji. Podstawowy mandat EBC, określony w art. 127 ust. 1 TFUE, dotyczy utrzymania stabilności cen, a nie stabilności finansowej. Jest sporne, czy EBC powinien angażować się we wsparcie płynnościowe pojedynczych instytucji finansowych, czy tylko całego systemu finansowego zagrożonego destabilizacją ${ }^{3}$.

2. W wykonywaniu uprawnień oraz powierzonych zadań i obowiązków ani EBC, ani krajowy bank centralny, ani członek któregokolwiek z ich organów decyzyjnych nie zwracają się o instrukcje ani ich nie przyjmują od instytucji, organów, ani jednostek organizacyjnych Unii, rządów państw członkowskich, ani jakiegokolwiek innego organu. Krąg podmiotowy został tu zakreślony szeroko. Wymienione podmioty zobowiązują się szanować tę zasadę i nie dążyć do wywierania wpływu na członków organów decyzyjnych EBC lub krajowych banków centralnych przy wykonywaniu ich zadań (art. 130 TFUE). Wskazaną niezależność instytucjonalną wzmacnia aspekt funkcjonalny, personalny i finansowy. Niezależność funkcjonalna rozumiana jest jako zdolność do samodzielnego formowania i realizacji polityki pieniężnej oraz samodzielnego podejmowania decyzji w celu wykonania zadań statutowych. Niezależność personalną tworzy zbiór procedur dotyczących powoływania i odwoływania organów decyzyjnych. Istota niezależności finansowej sprowadza się do trwałego formułowania zasad oraz podziału funduszy banku, a także do wykluczenia nacisku na decyzje banku dotyczące kwestii finansowych ${ }^{4}$.

3. Zgodnie $\mathrm{z}$ art. 282 ust. 3 TFUE EBC ma osobowość prawną. W każdym z państw członkowskich ma zdolność prawną i zdolność do czynności prawnych (art. 9 ust. 1 Statutu ESBC i EBC), o najszerszym zakresie, przyznanym przez ustawodawstwa krajowe osobom prawnym. Ma także zdolność prawnomiędzynarodową a jako podmiot międzynarodowego prawa publicznego jest uprawnio-

3 T. Knepka, Europejski Bank Centralny jako pożyczkodawca ostatniej instancji, [w:] Wielka encyklopedia prawa, t. 3. Prawo Unii Europejskiej, red. Z. Brodecki, Warszawa 2014, s. 72-73.

4 Tak A. Molisz, Europejski Bank Centralny, [w:] Wielka encyklopedia prawa, t. 3, s. 72. 
ny do uczestnictwa w pracach międzynarodowych instytucji oraz do zawierania umów międzynarodowych w zakresie spraw należących do jego kompetencji.

Działania i zaniechania EBC mogą być kontrolowane i interpretowane w sprawach i na warunkach traktatowych — przez Trybunał Sprawiedliwości UE (TSUE). EBC jest uprawniony traktatowo do wszczynania postępowań. Decyzja o wszczęciu postępowania przed TSUE jest podejmowana przez Radę Prezesów (organ decyzyjny EBC).

EBC działa na podstawie Traktatów i Statutu ESBC i EBC, dołączonych jako protokół do Traktatów (art. 129 ust. 2), a także na podstawie regulaminów wewnętrznych ${ }^{5}$. Należy też podkreślić, że — zgodnie z art. 131 TFUE — każde państwo członkowskie UE zapewnia zgodność swojego ustawodawstwa krajowego, w tym statutu krajowego banku centralnego, z Traktatami i Statutem ESB i EBC. Przepisy Statutu często są identyczne treściowo z przepisami traktatowymi.

Do rozporządzenia kapitałem EBC uprawnione są wyłącznie krajowe banki centralne. Każdy krajowy bank centralny ma w kluczu kapitałowym EBC określony udział procentowy.

4. Zgodnie z art. 129 ust. 1 TFUE ESBC jest kierowany przez organy decyzyjne EBC, którymi są Rada Prezesów i Zarząd.

Rada Prezesów EBC składa się z członków Zarządu EBC i prezesów krajowych banków centralnych państw członkowskich, których walutą jest euro (art. 283 ust. 1 TFUE). Rada Prezesów EBC nie jest więc organem kadencyjnym, jej skład zależy bowiem od tego, kto aktualnie zajmuje stanowisko prezesa banku centralnego w każdym z państw członkowskich należących do strefy euro, oraz od tego, kto aktualnie zajmuje stanowisko w Zarządzie EBC ${ }^{6}$. Rada Prezesów przyjmuje regulamin wewnętrzny, który określa organizację wewnętrzną EBC i jego organów decyzyjnych.

Rada Prezesów EBC uchwala wytyczne i podejmuje decyzje niezbędne do zapewnienia wykonania zadań powierzonych ESBC oraz ustala politykę pieniężną UE włącznie z decyzjami w sprawach celów monetarnych, podstawowych stóp procentowych, wielkości rezerw w ESBC, a nadto uchwala wytyczne w sprawie realizacji tych decyzji. Rada Prezesów ma wyłączne prawo do upoważnienia do emisji banknotów euro w Unii. Banknoty takie mogą emitować EBC i krajowe

5 Są to: a) Regulamin EBC — decyzja Europejskiego Banku Centralnego 2004/257/WE z dnia 19 lutego 2004 roku przyjmująca Regulamin Europejskiego Banku Centralnego (EBC/2004/2), Dz. Urz. UE L 80, s. 33, ze zm., uzupełniony regulaminem Rady ds. Nadzoru Europejskiego Banku Centralnego (Dz. Urz. UE L 182, s. 56, ze zm.); b) Regulamin Zarządu EBC — decyzja Europejskiego Banku Centralnego EBC/1999/7 z dnia 12 października 1999 roku concerning the Rules of Procedure of the Executive Board of the European Central Bank, Dz. Urz. WE L 314, s. 34; c) Regulamin Rady Ogólnej EBC — decyzja Europejskiego Banku Centralnego EBC/2004/12 z dnia 17 czerwca 2004 roku przyjmująca Regulamin Rady Ogólnej Europejskiego Banku Centralnego (Dz. Urz. UE L 230, s. 61); Statut — protokół (nr 4) do Traktatów.

${ }^{6}$ Zob. M. Górka, Europejski Bank Centralny, [w:] J. Barcz, M. Górka, A. Wyrozumska, Instytucje i prawo Unii Europejskiej, Warszawa 2017, s. 216. 
banki centralne. Banknoty emitowane przez EBC i krajowe banki centralne są jedynym środkiem płatniczym w Unii.

Rada Prezesów EBC podejmuje swe uchwały zwykłą większością przy kworum dwu trzecich, chyba że Statut przewiduje inaczej. W przypadku równej liczby głosów decydujący jest głos przewodniczącego. W razie braku kworum przewodniczący może zwołać posiedzenie nadzwyczajne bez wymogu kworum. W celu przyjęcia niektórych decyzji głosy członków Rady Prezesów EBC „ważone” są zgodnie z udziałami krajowych banków centralnych w subskrybowanym kapitale EBC. Od 2015 roku stosowany jest też tak zwany rotacyjny system głosowania, zawierający modyfikacje uwzględniające wielkość gospodarek krajów strefy euro i sektorów finansowych. Decyzja wymagająca kwalifikowanej większości zostaje podjęta, gdy głosy za jej przyjęciem reprezentują co najmniej dwie trzecie subskrybowanego kapitału EBC i co najmniej połowę akcjonariuszy. Prawo do głosowania jest wykonywane w zasadzie osobiście, jedynie wyjątkowo regulamin może dopuścić oddanie głosu za pomocą środków telekonferencyjnych. Zebrania Rady Prezesów są poufne. Może ona jednak zdecydować o podaniu wyniku obrad do publicznej wiadomości. Rada Prezesów zbiera się przynajmniej dziesięć razy w roku.

Zgodnie z art. 284 TFUE w posiedzeniach Rady Prezesów EBC mogą uczestniczyć - bez prawa głosowania - przewodniczący Rady i członek Komisji (instytucji UE). Przewodniczący Rady może przedłożyć wniosek do rozważenia przez Radę Prezesów EBC. Z kolei prezes EBC jest zapraszany do uczestniczenia w posiedzeniach Rady, kiedy dyskutuje ona o sprawach dotyczących celów i zadań ESBC. EBC kieruje sprawozdanie roczne z działalności ESBC i w sprawie polityki pieniężnej za rok ubiegły i rok bieżący do Parlamentu Europejskiego, Rady i Komisji, jak również do Rady Europejskiej. Prezes EBC przedstawia to sprawozdanie Radzie i Parlamentowi Europejskiemu, który może odbyć debatę generalną na tej podstawie. Co najmniej raz na kwartał EBC opracowuje i publikuje sprawozdania z działalności ESBC. Skonsolidowane zestawienie finansowe ESBC jest publikowane co tydzień. Prezes EBC i inni członkowie Zarządu EBC mogą - na żądanie Parlamentu Europejskiego lub z inicjatywy własnej — być przesłuchani przez właściwe komisje Parlamentu Europejskiego.

Zarząd EBC składa się z prezesa, wiceprezesa i czterech innych członków (art. 283 ust. 2). Wszyscy oni są mianowani przez Radę Europejską - w określonym traktatowo, specjalnym trybie — spośród osób o uznanym autorytecie i doświadczeniu zawodowym w dziedzinie pieniądza lub bankowości. Ich mandat trwa osiem lat i nie jest odnawialny. Członkami Zarządu mogą być tylko obywatele państw członkowskich UE. Jeżeli członek Zarządu przestał spełniać warunki konieczne do sprawowania swej funkcji lub dopuścił się poważnego uchybienia, Trybunał Sprawiedliwości może go zdymisjonować na wniosek Rady Prezesów EBC lub Zarządu EBC. Członkowie Zarządu w zasadzie nie mogą wykonywać żadnej innej zarobkowej lub niezarobkowej działalności zawodowej. 
Zarząd EBC jest odpowiedzialny za realizację polityki pieniężnej zgodnie z wytycznymi i postanowieniami Rady Prezesów EBC. Udziela on niezbędnych instrukcji krajowym bankom centralnym. Zarządza on bieżącą działalnością EBC, przygotowuje posiedzenia Rady Prezesów EBC, wykonuje inne uprawnienia przekazane mu przez Radę Prezesów EBC na zasadzie delegacji. Ponadto Zarząd może uzyskać w drodze delegacji pewne uprawnienia, o ile Rada Prezesów tak zdecyduje. Zarząd EBC podejmuje swe decyzje zwykłą większością oddanych głosów, a w razie równej ich liczby przeważa głos prezesa $\mathrm{EBC}$.

Mimo że art. 129 TFUE wśród organów EBC wymienia jedynie Radę Prezesów oraz Zarząd, to - dopóki w UE istnieją państwa członkowskie objęte „derogacją" — do organów decyzyjnych należy zaliczać także Radę Ogólną, będącą jedynym organem całego ESBC, a nie tylko Eurosystemu. Rada Ogólna składa się z prezesa i wiceprezesa EBC, prezesów krajowych banków centralnych wszystkich państw członkowskich UE (w tym państw spoza strefy euro). W posiedzeniach Rady Ogólnej mogą brać udział pozostali członkowie Zarządu EBC, ale bez prawa głosowania, oraz - analogicznie do posiedzeń Rady Prezesów EBC przewodniczący Rady UE i przedstawiciel Komisji. Rada Ogólna uchwala swój regulamin wewnętrzny. Rada Ogólna jest informowana przez prezesa EBC o decyzjach podjętych przez Radę Prezesów.

Rada Ogólna pełni przede wszystkim zadania przejściowe, związane z objęciem derogacją niektórych państw członkowskich UE. W szczególności pełni tu funkcję doradczą w przygotowaniach do zniesienia derogacji, wspomaga przygotowania niezbędne do nieodwołalnego ustalenia kursów wymiany na euro walut państw członkowskich objętych derogacją. Rada Ogólna ponadto jednak wspiera gromadzenie informacji statystycznych oraz działania sprawozdawcze EBC, bierze udział w sporządzaniu dorocznego raportu EBC, uczestniczy w ustalaniu jednolitych procedur rachunkowych i sprawozdawczych stosowanych przez krajowe banki centralne, uczestniczy w ustalaniu warunków zatrudnienia personelu EBC.

5. W związku z tym, że art. 228 ust. 1 TFUE przesądza, że ESBC składa się z EBC i krajowych banków centralnych wszystkich państw członkowskich UE, warto także podkreślić, że ESBC nie ma osobowości prawnej i dlatego jest kierowany przez organy decyzyjne EBC. ESBC nie posiada własnego majątku. Nie jest podmiotem praw i obowiązków. Nie może pozywać i być pozywanym. Nie dysponuje też własnym personelem. Dlatego też ESBC nie jest organem lub instytucją UE. Określa się go jako „ramy wykonywania władztwa monetarnego”. ESBC ma niewątpliwie unijny, ponadnarodowy charakter. Pojmowany jest głównie jako dwustopniowa, ale decyzyjnie scentralizowana organizacja bankowości centralnej, nie zaś organizacja typu federalnego. Centralne banki krajowe są w tym układzie komponentem zdecentralizowania, EBC zaś elementem centralistycznym. Co

7 Zob. S. Pawłowski, Europejski Bank Centralny w obliczu kryzysu zadtużenia, Warszawa 2014, s. 20-21. 
ważne, zgodnie ze Statutem ESBC, większość zadań systemu jest wykonywana przy współudziale krajowego komponentu całego systemu. W powiązaniu z aspektami kapitałowymi i organizacyjnymi należy więc podkreślić głębokie przenikanie się obu elementów - wspólnotowego i krajowego ${ }^{8}$. EBC zapewnia więc realizację zadań powierzonych ESBC bądź przez własne działania, bądź działania krajowych banków centralnych państw członkowskich UE (art. 9 ust. 2 Statutu ESBC i EBC). W dziedzinie współpracy międzynarodowej, związanej z zadaniami powierzonymi ESBC, to EBC decyduje o sposobie reprezentacji ESBC (art. 6 Statutu ESBC i EBC).

W zakresie uznanym za możliwy i odpowiedni, bez uszczerbku dla obowiązków organów decyzyjnych, EBC ma prawo zwracać się do krajowych banków centralnych w celu przeprowadzenia operacji stanowiących część zadań ESBC (art. 12 ust. 1 in fine Statutu ESBC i EBC). Obowiązkiem państw członkowskich UE jest między innymi zapewnić zgodność swego ustawodawstwa, w tym statutu banku centralnego, z Traktatami i Statutem ESBC i EBC. Statuty krajowych banków centralnych muszą przewidywać w szczególności, że kadencja prezesa krajowego banku centralnego nie będzie krótsza niż pięć lat. Prezes może zostać zwolniony z urzędu — z zachowaniem procedur gwarancyjnych — wyłącznie wówczas, gdy nie spełnia już warunków koniecznych do wykonywania swych funkcji lub dopuścił się poważnego uchybienia. Krajowe banki centralne mogą też wykonywać inne funkcje niż określone Statutem ESBC i EBC, ale na własną odpowiedzialność i z zastrzeżeniem, że nie uważa się ich za część funkcji ESBC (art. 14 Statutu ESBC i EBC).

6. Polski komponent (krajowy) Europejskiego Systemu Banków Centralnych — Narodowy Bank Polski — odpowiada standardom z uwzględnieniem, że Polska nie należy jeszcze do Eurosystemu. Zgodnie z art. 227 Konstytucji RP ${ }^{9}$ Narodowy Bank Polski jest centralnym bankiem państwa. Przysługuje mu wyłączne prawo emisji pieniądza oraz ustalania i realizowania polityki pieniężnej. Narodowy Bank Polski odpowiada za wartości polskiego pieniądza.

Organami Narodowego Banku Polskiego są: Prezes NBP, Rada Polityki Pieniężnej oraz Zarząd NBP. Prezes NBP jest powoływany przez Sejm na wniosek Prezydenta RP na okres sześciu lat. Prezes NBP nie może należeć do partii politycznej, związku zawodowego ani prowadzić działalności publicznej niedającej się pogodzić z godnością jego urzędu. Zgodnie z art. 103 ust. 1 i art. 108 Konstytucji RP nie może być jednocześnie posłem lub senatorem.

Prezes NBP wchodzi jako przewodniczący w skład Rady Polityki Pieniężnej, a także osoby wyróżniające się wiedzą z zakresu finansów, powoływane na sześć lat, w równej liczbie przez Prezydenta RP, Sejm i Senat. Rada Polityki Pieniężnej

8 Ibidem, s. 23.

9 Konstytucja Rzeczypospolitej Polskiej z dnia 2 kwietnia 1997 roku, Dz.U. Nr 78, poz. 483 z późn. zm. 
ustala corocznie założenia polityki pieniężnej i przedkłada je do wiadomości Sejmowi jednocześnie z przedłożeniem przez Radę Ministrów projektu ustawy budżetowej. RPP w ciągu pięciu miesięcy od zakończenia roku budżetowego składa Sejmowi sprawozdanie z wykonania założeń polityki pieniężnej.

Organizację i zasady działania Narodowego Banku Polskiego oraz szczegółowe zasady powoływania i odwoływania jego organów określa — zgodnie z art. 227 ust. 7 Konstytucji RP - ustawa. Dziś jest to ustawa z dnia 29 sierpnia 1997 roku o Narodowym Banku Polskim ${ }^{10}$.

7. W związku z przyszłym przystąpieniem Polski do strefy euro wskazuje się w literaturze przedmiotu konieczność zmiany zwłaszcza przepisu art. 227 ust. 1 Konstytucji $\mathrm{RP}^{11}$. Najbardziej miarodajną propozycją legislacyjną jawi się Projekt ustawy o zmianie Konstytucji z uzasadnieniem z 30 czerwca 2010 roku, przygotowany przez zespół naukowy ekspertów pod kierownictwem Krzysztofa Wójtowicza, powołanych w 2009 roku przez marszałka Sejmu B. Komorowskiego ${ }^{12}$. Umożliwienie wprowadzenia w Polsce wspólnej waluty euro obrazują zmiany proponowane $\mathrm{w}$ art. 1 pkt $2-6$ projektu oraz $\mathrm{w}$ art. 1 pkt 7 . Związane są one z dotychczasowymi przepisami Konstytucji RP, dającymi Narodowemu Bankowi Polskiemu wyłączne prawo emisji pieniądza oraz ustalania i realizowania polityki pieniężnej. Ponadto jednak obowiązująca Konstytucja RP normuje zagadnienia odpowiedzialności Prezesa NBP oraz kontroli nad tym bankiem odmiennie niż w prawie unijnym, które znalazłoby zastosowanie w Polsce po wprowadzeniu waluty euro. Wprowadzenie euro wymagałoby przekazania określonych kompetencji NBP oraz Rady Polityki Pieniężnej, choć NBP mógłby zachować pewne kompetencje poza sferą polityki pieniężnej, normowanej przez prawo pierwotne Unii Europejskiej. Konieczne jednak byłoby usunięcie z polskiego systemu prawnego tych przepisów, które mogłyby osłabiać skuteczność prawa unijnego w dziedzinie polityki pieniężnej oraz podważać niezależność NBP. Niezbędne więc staje się w szczególności dostosowanie też do prawa Unii Europejskiej przepisów o odpowiedzialności Prezesa NBP oraz o kontroli nad NBP.

10 Tekst jedn. Dz.U. z 2017 r. poz. 1373 ze zm. W literaturze przedmiotu przykładowo zob. A. Bień-Kacała, Narodowy Bank Polski, [w:] Wielka encyklopedia prawa, t. 6. Prawo konstytucyjne, red. A. Łabno, Warszawa 2016, s. 198-200; E. Knosala, R. Stasikowski, Status Narodowego Banku Polskiego w systemie organów państwa, „Przegląd Sejmowy” 2010, nr 1; M. Zubik, Narodowy Bank Polski. (Analiza konstytucyjno-ustrojowa), „Państwo i Prawo” 2001, nr 6; A. Bałaban, Konstytucyjna pozycja Narodowego Banku Polskiego a Unia Monetarna, [w:] Konstytucja i władza we wspótczesnym świecie. Doktryna - prawo - praktyka. Prace dedykowane Profesorowi Wojciechowi Sokolewiczowi na siedemdziesięciolecie urodzin, red. M. Kruk, J. Trzciński, J. Wawrzyniak, Warszawa 2002, s. 340-345.

11 Zob. przykładowo J. Jaskiernia, Członkostwo Polski w Unii Europejskiej a problem nowelizacji Konstytucji RP, „Żurawia Papers” 2004, nr 2, s. 72.

12 „Zmiany w Konstytucji RP dotyczące członkostwa Polski w Unii Europejskiej. Dokumenty z prac zespołu naukowego powołanego przez Marszałka Sejmu”, Wyd. Sejmowe 2010; w interesującym nas zakresie zwł. s. 9-10 i 16-17. 
W przytoczonym projekcie między innymi proponuje się więc wykreślenie NBP w art. 203 ust. 1 Konstytucji RP, wyliczającym organy objęte kontrolą NIK, czy w art. 198 ust. 1 wykreślenie Prezesa NBP jako podlegającego odpowiedzialności konstytucyjnej przed Trybunałem Stanu. Kluczowy dziś art. 227 Konstytucji miałby otrzymać następujące brzmienie:

1. Centralnym bankiem państwa jest Narodowy Bank Polski, który należy do Europejskiego Systemu Banków Centralnych. Narodowy Bank Polski zapewnia stabilność cen oraz realizuje zadania i wykonuje kompetencje określone w Traktatach stanowiących podstawę Unii Europejskiej oraz w ustawie. Narodowy Bank Polski jest w swojej działalności niezależny od innych organów państwowych.

2. Najwyższa Izba Kontroli może kontrolować Narodowy Bank Polski jedynie w zakresie, w jakim nie dotyczy to wykonywania uprawnień oraz zadań, o których mowa w ust. 1.

3. Organami Narodowego Banku Polskiego są Prezes Narodowego Banku Polskiego oraz Zarząd Narodowego Banku Polskiego.

4. Prezes Narodowego Banku Polskiego nie może należeć do partii politycznej, związku zawodowego ani prowadzić działalności publicznej niedającej się pogodzić z godnością jego urzędu.

5. Organizację i zasady działania Narodowego Banku Polskiego oraz szczegółowe zasady powoływania i odwoływania jego organów określa ustawa.

Przepis art. 227 ust. 1 miałby brzmienie zgodne z Traktatem o funkcjonowaniu Unii Europejskiej. Definiuje on nową rolę ustrojową NBP jako organu będącego częścią ESBC i umacnia jego niezależność.

Zagadnienie odpowiedzialności Prezesa NBP powinno zostać uregulowane w ustawach zwykłych zgodnie z traktatami stanowiącymi podstawę Unii Europejskiej oraz statutem Europejskiego Systemu Banków Centralnych. Uchylenie zaś przepisów dotyczących Rady Polityki Pieniężnej byłoby dekonstytucjonalizacją tego organu, co nie musiałoby prowadzić do jego likwidacji, a jedynie nowego określenia jego statusu ustawowego.

\section{EUROPEAN CENTRAL BANK}

\section{Summary}

The article is devoted to the status of the European Central Bank in the European System of Central Banks. The author discusses the composition and competences of the European Central Bank, its functions and tasks, internal decision-making bodies, and the mode of procedure. Moreover, the links of the European Central Banks with the system of national central banks is also shown, including the current status of the National Bank of Poland and constitutional changes necessary in Poland in order to adopt the euro in the future.

Keywords: European Central Bank, European System of Central Banks, Eurosystem, National Bank of Poland 


\section{BIBLIOGRAFIA}

Bałaban A., Konstytucyjna pozycja Narodowego Banku Polskiego a Unia Monetarna, [w:] Konstytucja i władza we wspótczesnym świecie. Doktryna - prawo - praktyka, red. M. Kruk, J. Trzciński, J. Wawrzyniak, Warszawa 2002.

Bień-Kacała A., Narodowy Bank Polski, [w:] Wielka encyklopedia prawa, t. 6. Prawo konstytucyjne, red. A. Łabno, Warszawa 2016.

Górka M., Europejski Bank Centralny, [w:] J. Barcz, M. Górka, A. Wyrozumska, Instytucje i prawo Unii Europejskiej, Warszawa 2017.

Jaskiernia J., Członkostwo Polski w Unii Europejskiej a problem nowelizacji konstytucji RP, „Żurawia Papers" 2004, nr 2.

Knepka T., Europejski Bank Centralny jako pożyczkodawca ostatniej instancji, [w:] Wielka encyklopedia prawa, t. 3. Prawo Unii Europejskiej, red. Z. Brodecki, Warszawa 2014.

Knosala E., Stasikowski R., Status Narodowego Banku Polskiego w systemie organów państwa, „Przegląd Sejmowy” 2010, nr 1.

Molisz A., Europejski Bank Centralny, [w:] Wielka encyklopedia prawa, t. 3. Prawo Unii Europejskiej, red. Z. Brodecki, Warszawa 2014.

Pawłowski S., Europejski Bank Centralny w obliczu kryzysu zadtużenia, Warszawa 2014.

Zubik M., Narodowy Bank Polski. (Analiza konstytucyjno-ustrojowa), „Państwo i Prawo” 2001, nr 6. 